\title{
Antifungal evaluation studies of copper sulfide nano-aquaformulations and its impact on seed quality of rice (Oryzae sativa)
}

\author{
Anjali Sidhu $^{1} \cdot$ Heena Barmota ${ }^{1} \cdot$ Anju Bala $^{2}$
}

Received: 8 July 2017/Accepted: 22 September 2017/Published online: 4 October 2017

(c) The Author(s) 2017. This article is an open access publication

\begin{abstract}
Surface capped copper sulfide nano-aquaformulations were prepared by in situ combination of copper ions with sulfide ions using sonochemical method, followed by microwave irradiations, in the presence of capping agents. Prepared nano-aquaformulations were characterized for particle size, morphology and optical properties. The in vitro antifungal evaluations studies indicated multifold efficacy against $\mathrm{Al}$ ternaria alternata, Drechslera oryzae and Curvularia lunata in comparison to standard used. The in vivo seed treatment on discoloured paddy seeds showed the optimum results on application@ @ $7 \mu \mathrm{g} / \mathrm{ml}$ for $2 \mathrm{~h}$ in case of citrate capped copper sulfide nanoformulation $\left(\mathrm{NCuS}_{3}\right)$. Significant reduction in seed rot and seedling blight was observed with favourable effect on germination and growth parameters at this concentration.
\end{abstract}

Keywords Copper sulfide · Nano-aquaformulations · Poisoned food technique - Phytopathogenic fungi . Mycelium growth

\section{Introduction}

The modern agriculture requisites the exploration of substances that exist in nature and are simple for nature to interpret them. There is continuous demand of eco-friendly

Anju Bala

anjalisidhu@pau.edu

1 Department of Chemistry, Punjab Agricultural University, Ludhiana, Punjab, India

2 Department of Plant Breeding and Genetics, Punjab Agricultural University, Ludhiana, Punjab, India formulated safe bioactive substances in the agricultural world, because of toxic nature of the existing organic molecules, toxic organic formulations and development of resistance against them in the pathogens. Alternative safe water base formulations (http://www.azom.com/article.aspx?ArticleID= 13694), are recognizably in demand, owing to increase in government regulations and restrictions, outrightly banning of products that have inherent toxicology and adverse environmental impact (Richardson 1997).

Copper $(\mathrm{Cu})$ based fungicides are used world-wide as various formulations viz. Cupric sulphate, Bordeaux mixture, copper dugtdrazubium sulphate, copper oxychloride, copper zinc chromate, cupric carbonate, cuprous oxide, burgundy mixture, copper hydroxide and organo coppers. The toxicity of copper is largely due to its tendency to alternate between its cuprous, $\mathrm{Cu}(\mathrm{I})$ and cupric $\mathrm{Cu}(\mathrm{II})$ oxidation states (Santra 2014), which get finally detoxified in nature by sulfidation (Wang et al. 2013). There are various methodologies that are usually proposed and practised to detoxify copper (Santra 2014), prior to actual detoxification by nature. Efficacy of the copper compounds can also be considerably improved by reducing the particle size (Torgeson 1967), as it results in more surface area available per gram of product (Navarro et al. 2008), advocating exploration of nano-technological applications in agriculture. Water based aqueous formulations, consisting of water insoluble active ingredients dispersed in water, is one of the most pertinent methodologies for the development of green pesticides that have limited application for copper fungicides (http://www.azom.com/article. aspx?ArticleID=13694).

On nanotechnological front, studies on copper nanoparticles ( $\mathrm{Cu} \mathrm{NPs})$ and copper oxide nanoparticles (CuO NPs) have been reported for phytopathological and phyto-applications. Nanotoxicological fronts for $\mathrm{Cu}$ 
fungicides are normally patented for methodologies meant for slow and controlled delivery of copper ions from the formulations. Santra (2014) invented copper-silica-based nanoformulation to treat citrus canker, inhibiting the growth of mold and mildew. A worth patent of the BASF company (Schneider et al. 2011) viz. polymer entangled CuNPs, showed improved efficiency against phytopathogenic fungus on vines (Gogos et al. 2012) in comparison to normal copper formulations (by $8 \%$ ). CuNPs absorbed in chitosan hydrogel had positive effects on tomato growth and quality (Juarez-Maldonado et al. 2016). It is believed that the stimulatory effects of CuNPs are related to the induction of antioxidant activity ( $\mathrm{Fu}$ et al. 2014). Copper nanoparticles have been found to increase germination percentage of wheat (Triticum aestivum) on seed treatment while severely reducing seedling vigor. $\mathrm{CuO}$ NPs have shown strong inhibitory effects on higher plants viz. Lemna minor (Guanling et al. 2016) and Lactuca sativa (Liu et al. 2016), at higher concentrations. Copper oxide nanoparticles are reported to induce DNA damage in agricultural and grassland plants. Significant plant growth inhibition has been reported for radish $(R$. sativus), perennial ryegrass (L. perenne), and annual ryegrass (Lolium rigidum) under controlled laboratory conditions (Atha et al. 2012). The most relevant study CuO NPs is on rice $(O$. sativa) showed that seed germination was not affected by $\mathrm{CuO}$ NPs at any of the investigated concentrations. At the concentration of $2000 \mathrm{mg} \mathrm{L}^{-1}$, the root elongation (97.28\% for rice), and the shoot length of maize was reduced by $30.98 \%$ (Ruttkay-Nedecky et al. 2017) by their applications. There is not literature on seed treatment of $\mathrm{CuS}$ in any form on any crop but still scanty investigation have been published on antimicrobial potential of CuS NPs in solid state (Chakraborty et al. 2016; Prabhavathi et al. 2015).

Copper sulfide $(\mathrm{CuS})$ is one of the most detoxified form of copper (Baek 2017; Baek and Kim 2017; Guo et al. 2013; Wang et al. 2013), natural, thermally stable (Rao et al. 2016), water insoluble (Guo et al. 2013) still retaining the biopotential of copper (Chakraborty et al. 2016; Prabhavathi et al. 2015). It is relatively safe and non-toxic behaviour to humans (Guo et al. 2013) and limited literature on synthesis and biopotential on water dispersed $\mathrm{CuS}$ nanoparticles prompted us to prepare the novel surface protected formulations of nano-copper sulfide in aqueous media, for the evaluation of mycocidal potential against various agriculturally important phytopathogenic fungi. To best of the author's knowledge it is the first reporting on in vitro myotoxicity along with on seed germination and seed quality parameters, on discoloured rice seeds, by application.

\section{Materials and methods}

\section{Instrumentation used}

Absorption spectra of nanoparticles were recorded in aqueous, using UV-1800 Shimadzu Double-beam Spectrophotometer. The measurements were carried out using quartz cell in the wavelength range of $200-800 \mathrm{~nm}$. The morphology and size of nanoparticles were recorded in Hitachi Transmission Electron Microscope Hi-7650 at an accelerated voltage of $200 \mathrm{kV}$ by casting a drop of particle solution onto a 200-mesh carbon coated copper grid from EMN laboratory, Punjab Agricultural University, Ludhiana.

\section{Synthesis of copper sulfide nano-aquaformulations $\left(\mathrm{NCuS}_{1-3}\right)$}

$30 \mathrm{ml}$ of copper nitrate trihydrate $\left(\mathrm{Cu}\left(\mathrm{NO}_{3}\right)_{2} \cdot 3 \mathrm{H}_{2} \mathrm{O}\right)$ solution $(0.001 \mathrm{M})$, prepared in ethylene glycol, was added dropwise to $30 \mathrm{ml}$ of sodium sulfide aqueous solution $(0.001 \mathrm{M})$, during sonication, along with a pinch of cetyltrimethylammonium bromide (CTAB) (surfactant). The solution was irradiated with microwaves for $30 \mathrm{~s}$ and allowed to cool down at the room temperature. Different capping agents viz polyvinyl pyrollidone (PVP), 4-aminobutyric acid (GABA) and tri-sodium citrate $(0.3 \mathrm{~g})$ dissolved in $20 \mathrm{ml}$ distilled water was added to above prepared solution during sonication, which was continued for another $15 \mathrm{~min}$, to get surface stabilized copper sulfide nanoparticles $\mathbf{N C u S}_{\mathbf{1 - 3}}$, respectively.

The prepared $\mathbf{N C u S}_{\mathbf{1 - 3}}(0.0005 \mathrm{M}, 35.85 \mu \mathrm{g} / \mathrm{ml})$ were retained as such as stock solution, which was further diluted by adding autoclaved water, as and when required.

\section{Antifungal evaluation of $\mathrm{NCuS}_{1-3}$}

Antifungal activity of copper sulfide nano-aquaformulations $\left(\mathrm{NCuS}_{1-3}\right)$ was tested against pathogenic fungi of rice viz. Alternaria alternata, Drechserla oryzae and Curvularia lunata at different concentration viz. 5, 6, 7, 8, 9, 10, $15 \mu \mathrm{g} / \mathrm{ml}$ by poisoned food technique (Nene and Thapliyal 1993). The cultures of phytopathogenic fungi were obtained from Seed Pathology laboratory of Punjab Agricultural University, Ludhiana. These concentrations were further tested on potato dextrose agar (PDA) and the results were validated on the test fungi.

\section{In vitro studies (poisoned food technique method)}

PDA medium was prepared using $250 \mathrm{~g}$ peeled potato, $20 \mathrm{~g}$ dextrose and $20 \mathrm{~g}$ agar in 11 water which was then 
autoclaved for half an hour. $36 \mathrm{ml}$ of PDA media was taken in the round bottom flask to which $14 \mathrm{ml}$ of stock solution $(35.85 \mu \mathrm{g} / \mathrm{ml})$ of the test formulation was added to give the resulting $10 \mu \mathrm{g} / \mathrm{ml}$ of NCuS-PDA concentrate. The contents of the flask were poured aseptically into the Petri plates. Similarly, $7 \mu \mathrm{g} / \mathrm{ml}$ and lower concentration up to 5 $\mu \mathrm{g} / \mathrm{ml}$ were prepared using normality equation. Test samples, however, was replaced by equal amount of PDA only in the control set. After solidification of the medium a $3 \mathrm{~mm}$ culture disc of mycelium, the test fungus was aseptically placed to each Petri plate and was incubated at $25 \pm 1{ }^{\circ} \mathrm{C}$. The efficacy of $\mathrm{NCuS}_{1-3}$ treatment was evaluated at the time intervals of $3,5,7$ and 9 days by measuring the diameter of fungal colonies. The average diameter of fungal colonies was measured on 9th day after inoculation. The percent mycelial growth inhibition was recorded using the following formula:

\section{Results and discussion}

Surface protected copper sulfide nanoparticles $\left(\mathrm{NCuS}_{1-3}\right)$ in aqua-dispersed form were synthesized by sonochemical irradiation method. $\mathrm{Cu}^{2+}$ ions from $\mathrm{Cu}\left(\mathrm{NO}_{3}\right)_{2}$ in ethylene glycol $\left(\mathrm{HOCH}_{2} \mathrm{CH}_{2} \mathrm{OH}\right)$ solution was made to combine with $\mathrm{S}^{2-}$ from sodium sulfide $\left(\mathrm{Na}_{2} \mathrm{~S}\right)$ solution, while sonication, forming copper sulfide nanoparticles, which were stabilized using different stabilizing agents viz. polyvinyl pyrollidone (PVP) (Fig. 1a), 4-aminobutyric acid (GABA) (Fig. 1b) and tri-sodium citrate (Fig. 1c).

\section{Characterization of copper sulfide nanoaqua- formulation $\left(\mathrm{NCuS}_{1-3}\right)$}

The morphological, particles size and optical properties of synthesized surface protected copper sulfide nanoparticles

Percent radial growth inhibition $=\frac{\text { Radial growth of fungal colony in control }- \text { Radial growth of fungal colony in treatment }}{\text { Radial growth of fungal colony in control }} \times 100$

The antifungal activity was expressed in terms of percent radial growth inhibition. The $\mathrm{ED}_{50}$ and $\mathrm{ED}_{90}$ value (effective dose at which 50 and $90 \%$ inhibition of fungal growth occurred) were calculated from percent radial growth inhibition.

\section{In vivo studies using rolled paper towel method}

To get insight into the effect of $\mathrm{NCuS}$ seed treatment on various pathological and physiological aspects, fungi infested discoloured rice seeds were used and seedling symptoms test of treated as well untreated seeds were performed using rolled paper towel method (ISTA 1999). Hundred seeds of rice (discoloured as well as healthy) were treated with the test formulation of $\mathrm{NCuS} \mathrm{@} \mathrm{5-10} \mu \mathrm{g} / \mathrm{ml}$ and captan@0.25\% seeds by dipping the seeds in test and standard fungicide solutions for $1 \mathrm{~h}$. The seedlings were evaluated after 10 days and data were recorded on seed germination, root length (RL), shoot length (SL), number of rotten seeds and blighted seedlings. Vigour index was calculated using formula given by Abdul-Baki and Anderson (1973).

Vigour index $=$ Dry weight $\times$ percent germination
(CuS-NPs) in aqua-dispersed form were studied by Transmission Electron Microscopy (TEM) and UV-Visible spectrophotometric studies. Morphology of $\mathrm{CuS}$ prepared was independent of the capping agent used with slight variation in the size. Shape analogy indicated from TEM morphograph showed distorted spherical to oval shapes of $\mathrm{CuS}$ nanoparticles with slight aggregations. The particle sizes were least in $\mathrm{NCuS}_{3}$ (Fig. 2d), followed by $\mathrm{NCuS}_{2}$ (Fig. 2c) and $\mathrm{NCuS}_{1}$ (Fig. 2b). The average particle size was in the range from 8 to $14 \mathrm{~nm}$ (Fig. 3). The trends of optical properties were in consonance with tem observations. The $\lambda_{\max }$ values in all the cases were lying in the range of 218-220 $\mathrm{nm}$ (Fig. 4) indicating the similarity in average size of the particles in all the samples. These values were slightly blue shifted, in comparison to the naked $\mathrm{CuS}$ nanoparticles $\left(\lambda_{\max }=230 \mathrm{~nm}\right)$, which is due to the combined effect of size reduction (Agnitotri et al. 2014) due to capping agents. The size range and the optical properties of $\mathrm{NCuS}_{1-3}$ are given in Table 1 .

To best of the author's knowledge, in situ synthesis of copper sulfide as nanoaqua-dispersed formulation form have no reporting previously. However, prepared CuS NPs in solid form have been reported using different sulfide sources viz. sodium sulfide (Huang et al. 2017; Riyaz et al. 2016; Ayodhya et al. 2016; Shamsipur et al. 2013; Castillon-Barraza et al. 2011; Ding et al. 2010), sodium thiosulfate (Nafees et al. 2015; Kundu and Pradhan 2013; 
Fig. 1 Physical representation of $\mathbf{a} \mathrm{NCuS}_{1}, \mathbf{b} \mathrm{NCuS}_{2}, \mathbf{c} \mathrm{NCuS}_{3}$
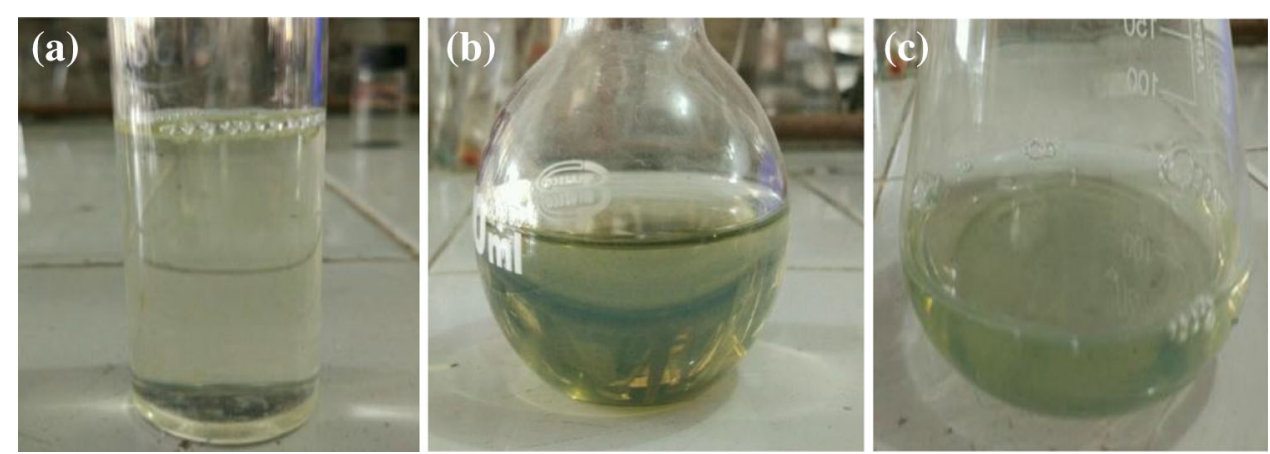

Fig. 2 TEM analysis of a naked $\mathrm{CuS}$, b NCuS1, c $\mathrm{NCuS} 2, \mathbf{d} \mathrm{NCuS} 3$
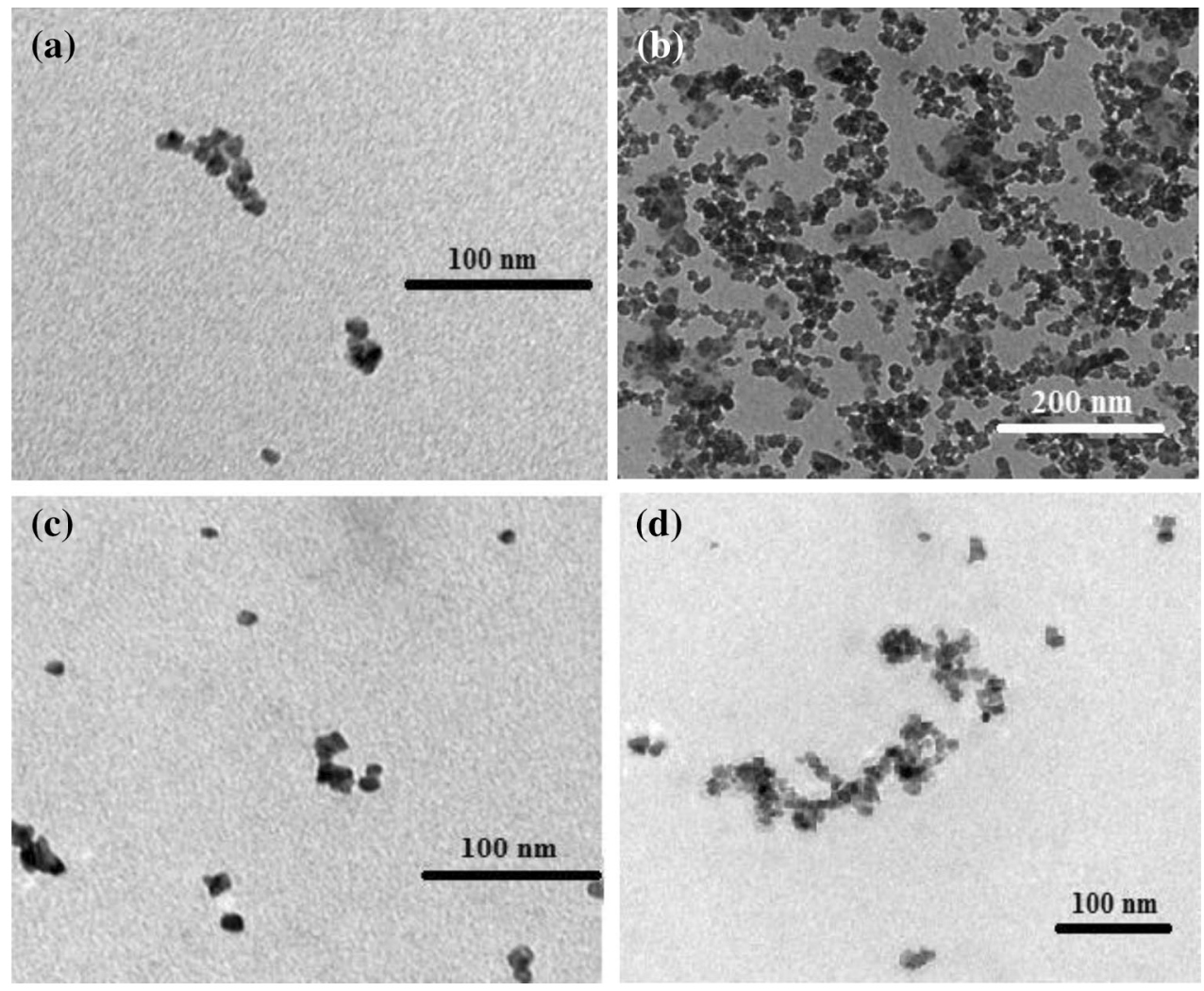

\%
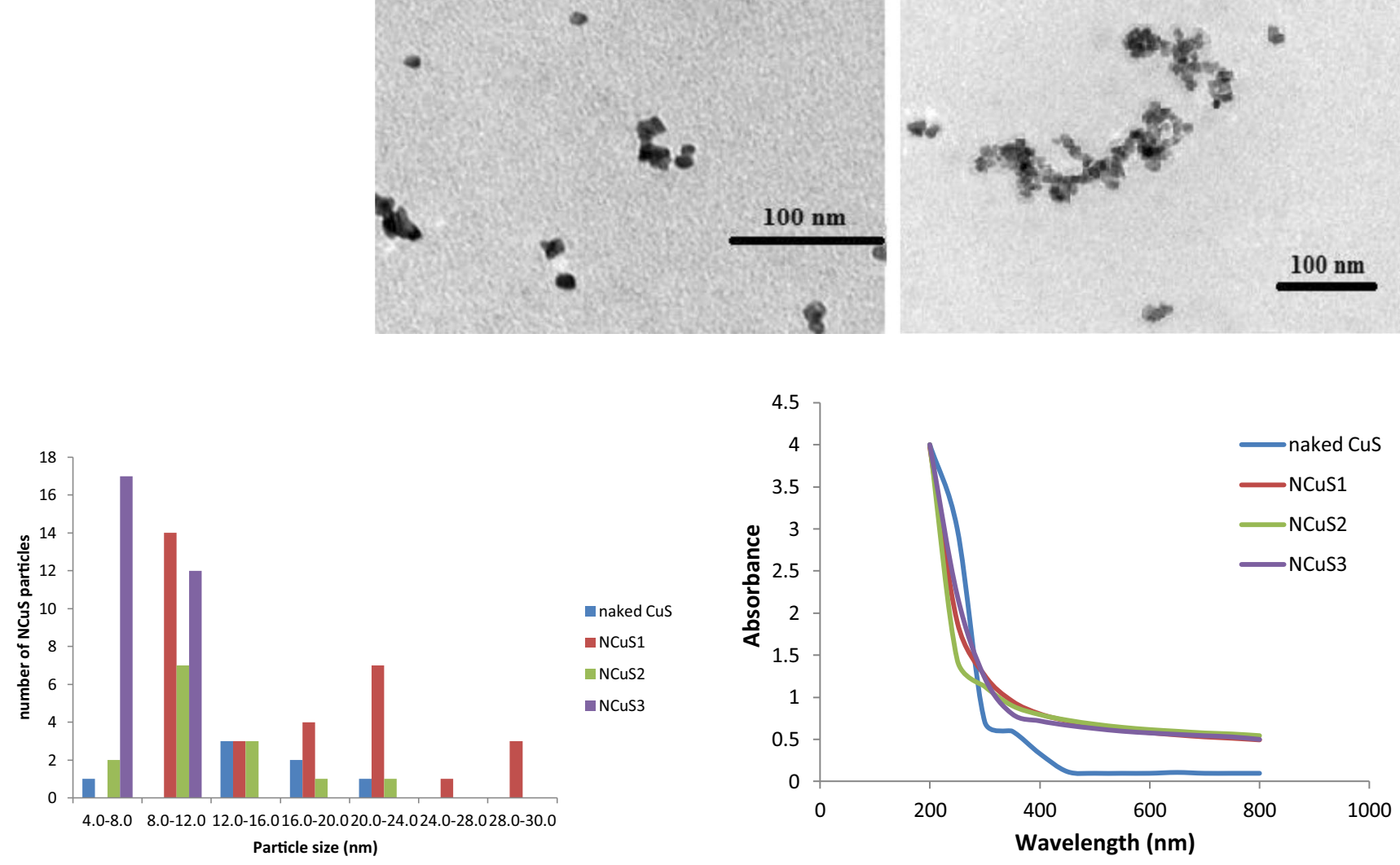

naked CuS

- NCuS1

- NCUS2

- NCuS3



Fig. 3 Particles size distribution of $\mathrm{NCuS}$

Fig. $4 \mathrm{UV}-\mathrm{V}$ is spectra of $\mathrm{NCuS}$ 
Table 1 Size range and absorption data of prepared samples of $\mathrm{NCuS}_{1-3}$

\begin{tabular}{|c|c|c|c|c|c|c|c|}
\hline S. No. & Sample name & Copper source & Sulfide source & Capping agent & Absorption peak (nm) & Range of particle size $(\mathrm{nm})$ & Average size $(\mathrm{nm})$ \\
\hline 1. & Naked CuS & Copper nitrate & Sodium sulfide & - & 230 & $7-22.5$ & 14 \\
\hline 2. & $\mathrm{NCuS}_{1}$ & Copper nitrate & Sodium sulfide & PVP & 218 & $10-30$ & 12 \\
\hline 3. & $\mathrm{NCuS}_{2}$ & Copper nitrate & Sodium sulfide & GABA & 219 & $4.5-22$ & 10 \\
\hline 4. & $\mathrm{NCuS}_{3}$ & Copper nitrate & Sodium sulfide & Citrate & 220 & $4-12$ & 8 \\
\hline
\end{tabular}

Table 2 Percent radial growth inhibition of the test fungi used against different samples of $\mathrm{NCuS}_{1-3}$ on the 9 th day of inoculation

\begin{tabular}{|c|c|c|c|c|}
\hline \multirow[t]{2}{*}{ Samples } & \multirow[t]{2}{*}{ Concentration $(\mu \mathrm{g} / \mathrm{ml})$} & \multicolumn{3}{|c|}{ Percent radial growth inhibition } \\
\hline & & A. alternata & D. oryzae & C. lunata \\
\hline \multirow[t]{5}{*}{$\mathrm{NCuS}_{1}$} & 3 & 12 & 11 & 19 \\
\hline & 5 & 32 & 27 & 33 \\
\hline & 7 & 58 & 41 & 57 \\
\hline & 10 & 79 & 61 & 78 \\
\hline & 15 & 100 & 100 & 100 \\
\hline \multirow[t]{5}{*}{$\mathrm{NCuS}_{2}$} & 3 & 19 & 27 & 9 \\
\hline & 5 & 29 & 40 & 20 \\
\hline & 7 & 48 & 57 & 34 \\
\hline & 10 & 76 & 77 & 56 \\
\hline & 15 & 100 & 100 & 100 \\
\hline \multirow[t]{5}{*}{$\mathrm{NCuS}_{3}$} & 3 & 37 & 37 & 32 \\
\hline & 5 & 45 & 50 & 44 \\
\hline & 7 & 64 & 76 & 62 \\
\hline & 10 & 99 & 97 & 91 \\
\hline & 15 & 100 & 100 & 100 \\
\hline \multirow[t]{4}{*}{ Captan $^{\mathrm{a}}$} & 200 & 35 & 40 & 39 \\
\hline & 300 & 58 & 60 & 62 \\
\hline & 400 & 73 & 75 & 71 \\
\hline & 500 & 87 & 90 & 84 \\
\hline
\end{tabular}

${ }^{a}$ Standard fungicide ( $N$-trichloromethyl-thio-4-cyclohexene-1,2dicarboximide)

Yang et al. 2013), thiourea (Han et al. 2016; Priyadharshini and Rajagopal 2015; Nafees et al. 2015) and thioacteamide (You et al. 2017). The size of nano $\mathrm{CuS}$ have been found to be in consonance with the reported literature. The $\lambda_{\max }$ values of capped samples $\left(\mathrm{NCuS}_{1-3}\right)$ were lower than the naked copper sulfide nanoparticles (Ajibade and Botha 2016; Riyaz et al. 2016; Priyadharshini and Rajagopal 2015; Nandipha 2015; Suja et al. 2013; Hosseini et al. 2012) as per our results. The values of $\lambda_{\max }$ were liable to change with the amount and type of capping used for metal nanoparticles. With the increase in level of capping the size reduces and in turn, the $\lambda_{\max }$ value get relatively blue shifted (Rani 2016), which is the most probable explanation for the altered optical properties of nanoparticles when capped.

\section{In vitro antifungal evaluation of $\mathrm{NCuS}_{1-3}$}

The antifungal evaluation study of $\mathrm{NCuS}$ having different capping agents viz PVP, GABA and citrate at different concentrations viz $15,10,7,5$ and $3 \mu \mathrm{g} / \mathrm{ml}$, was done using poisoned food technique against three economically important phytopathogenic fungi (Alternaria alternata, Drechslera oryzae and Curvularia lunata). The results were expressed in terms of percent radial growth inhibition, at different test concentrations (Table 2), from which $\mathrm{ED}_{50}$ and $\mathrm{ED}_{95}$ values were calculated using polo software programme (Table 3). Captan ( $N$-trichloromethyl-thio-4-cyclohexene-1,2-dicarboximide) was used as standard fungicide against the test fungi. The Table 2 clearly implicates the remarkably high bioactivity of copper sulfide nanoformulations. The zone of inhibition was equivalent to standards at much lower concentrations of $\mathrm{NCuS}$ in all the test samples against all the test fungi. $\mathrm{NCuS}_{3}$ was most effective against all the test fungi with $>90 \%$ inhibition at $10 \mu \mathrm{g} / \mathrm{ml}$ on 9 th day of inoculation. Radial growth inhibition of test fungi at concentration of $10 \mu \mathrm{g} / \mathrm{ml}$ are shown in Figs. 5, 6, 7. The more comprehensive interpretation came out to be in the form of $\mathrm{ED}_{50}$ and $\mathrm{ED}_{90}$ values. The comparative account revealed $\mathrm{ED}_{50}$ and $\mathrm{ED}_{90}$ values lower than 11.0 and $14 \mu \mathrm{g} / \mathrm{ml}$, respectively. These values are multifold lower than the standard fungicides, captan used against the respective fungi. $\mathrm{NCuS}_{3}$ was the best against D. oryzae with $\mathrm{ED}_{50}$ and $\mathrm{ED}_{90}$ of 5.0 and $7.0 \mu \mathrm{g} /$ $\mathrm{ml}$, respectively. Against A. alternata, $\mathrm{NCuS}_{3}$ was $\mathrm{ED}_{50}$ and $\mathrm{ED}_{90}$ of 5.5 and $8.3 \mu \mathrm{g} / \mathrm{ml}$, respectively. $\mathrm{NCuS}_{3}$ nearly followed the same trend against $C$. lunata, with $\mathrm{ED}_{50}$ and $\mathrm{ED}_{90}$ of 6.0 and $8.0 \mu \mathrm{g} / \mathrm{ml}$, respectively.

Practically, no literature is available on the antifungal evaluation of study $\mathrm{f} \mathrm{NCuS}$ as aqua formulations. However, limited reported literature on $\mathrm{CuS}$ NPs in solid state revealed appreciable bio potential of CuS NPs. The synthesized nanoparticles (CuS-I and CuS-II) possibly gets adsorbed on the surface of the cell wall of microorganisms to disturb the respiration process, leading to breakdown of the permeability barrier of the cell and resulting in 
Table 3 Antifungal activity of $\mathrm{NCuS}_{1-3}$ in terms $\mathrm{ED}_{50}$ values $(\mu \mathrm{g} / \mathrm{ml})$

\begin{tabular}{|c|c|c|c|c|c|c|}
\hline \multirow[t]{2}{*}{ Samples } & \multicolumn{2}{|c|}{ A. alternata } & \multicolumn{2}{|c|}{ D. oryzae } & \multicolumn{2}{|c|}{ C. lunata } \\
\hline & $\mathrm{ED}_{50}$ & $\mathrm{ED}_{90}$ & $\mathrm{ED}_{50}$ & $\mathrm{ED}_{90}$ & $\mathrm{ED}_{50}$ & $\mathrm{ED}_{90}$ \\
\hline $\mathrm{NCuS}_{1}$ & 6.7 & 9.6 & 8.0 & 10.0 & 8.0 & 10.5 \\
\hline $\mathrm{NCuS}_{2}$ & 8.3 & 11.0 & 7.0 & 9.5 & 11.5 & 14.0 \\
\hline $\mathrm{NCuS}_{3}$ & 5.5 & 8.3 & 5.0 & 7.0 & 6.0 & 8.0 \\
\hline Captan $^{\mathrm{a}}$ & 240 & 430 & 250 & 390 & 270 & 405 \\
\hline
\end{tabular}

${ }^{a}$ Standard fungicide ( $N$-trichloromethyl-thio-4-cyclohexene-1,2-dicarboximide)

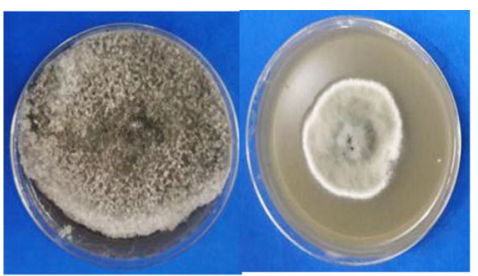

(a)

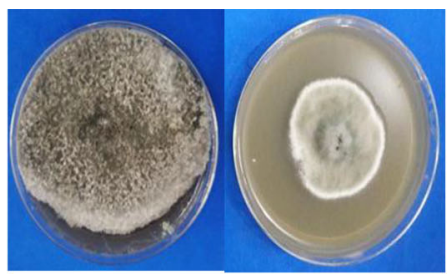

(b)



(c)

Fig. 5 Antifungal activity against A. alternata a $\mathrm{NCuS}_{1}, \mathbf{b} \mathrm{NCuS}_{2}, \mathbf{c} \mathrm{NCuS}_{3}$

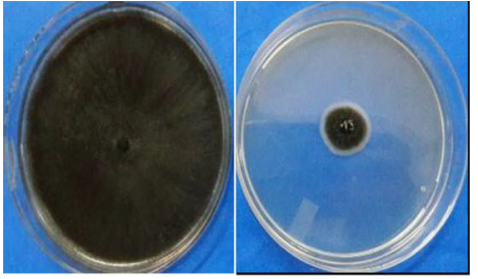

(a)

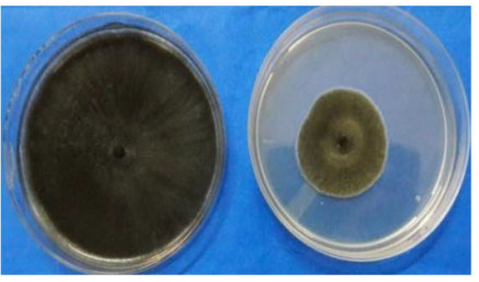

(b)

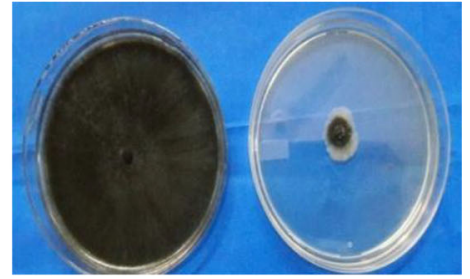

(c)

Fig. 6 Antifungal activity against $D$. oryzae $\mathbf{a ~} \mathrm{NCuS}_{1}$, b $\mathrm{NCuS}_{2}$, c $\mathrm{NCuS}_{3}$

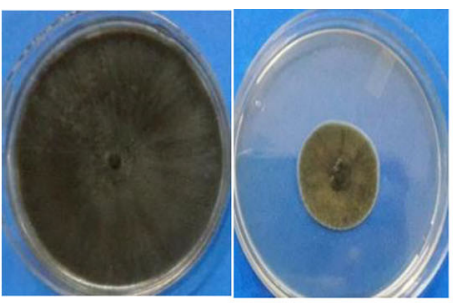

(a)

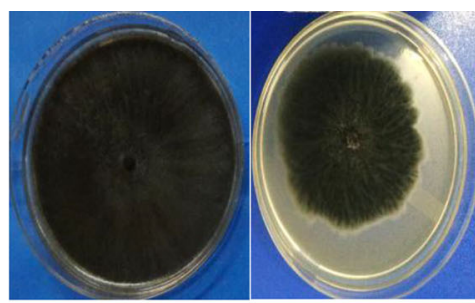

(b)

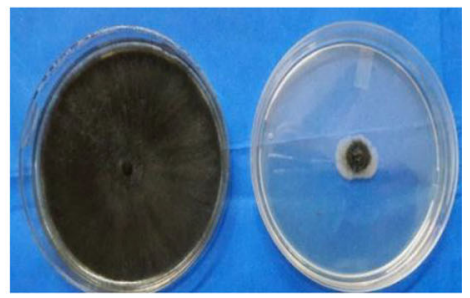

(c)

Fig. 7 Antifungal activity against $C$. lunata $\mathbf{a} \mathrm{NCuS}_{1}$, b $\mathrm{NCuS}_{2}, \mathbf{c} \mathrm{NCuS}_{3}$

interference with, the normal cell process inhibiting further growth of the microorganisms (Chakraborty et al. 2016). The antimicrobial and antifungal activities of pyrolytically synthesized CuS NPs were found dependent on morphology of NPs (Chakraborty et al. 2016). These results were contradictory to our results, which were concentration dependent (when used in the concentration lower than $15 \mu \mathrm{g} / \mathrm{ml}$ ) and independent of morphology and size of NPs in the average size range $8-14 \mathrm{~nm}$.

\section{In vitro seed treatment}

The seeds were treated with different concentrations of $\mathrm{NCuS}_{1}$ and $\mathrm{NCuS}_{3}$. The different concentrations used were $6-10 \mu \mathrm{g} / \mathrm{ml}$ and the seeds were dipped into the formulations for different time intervals starly from 1 to $6 \mathrm{~h}$, the results indicated that dipping into $\mathrm{NCuS}_{3}$ for $2 \mathrm{~h}$ inflicted the best results to inhibit the fungal mycoflora (Fig. 8) at minimum concentration of @ $7 \mu \mathrm{g} / \mathrm{ml}$. 


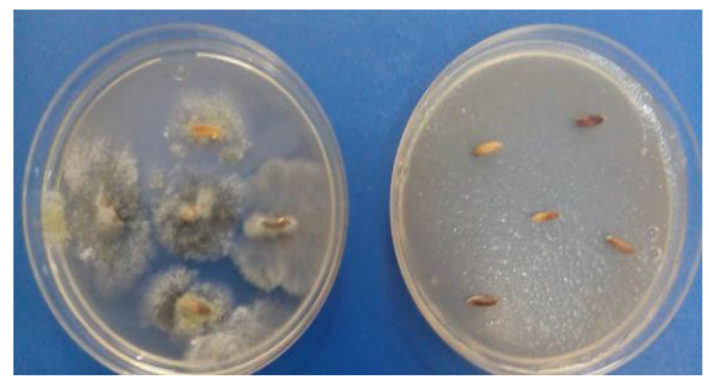

Fig. 8 Inhibition the fungal mycoflora at $7 \mu \mathrm{g} / \mathrm{ml}$ on treatment by $\mathrm{NCuS}_{3}$ for $2 \mathrm{~h}$

\section{In vivo evaluation of $\mathrm{NCuS}_{3}$}

In vitro studies indicated that the most active value for maximum inhibition of fungal growth lies below $10 \mu \mathrm{g} / \mathrm{ml}$. So different concentrations viz. 5, 6, 7 and $8 \mu \mathrm{g} / \mathrm{ml}$ were tested for seed treatment studies. There was a decrease of seed rot and seedling blight with favourable effect on seed quality parameters such as seed germination, shoot length, root length and vigour index of seedlings at low concentrations. Reduction in seed rot and seedling blight was 60 and $83.3 \%$, respectively, when the seeds were treated with $7 \mu \mathrm{g} / \mathrm{ml} \mathrm{NCuS}{ }_{3}$ (Fig. 9) which was significantly higher than percentage reduction in seed rot (50\%) and seedling blight $(73.3 \%)$ in captan treated seeds. Root length of the seedlings was also significantly increased in $\mathrm{NCuS}_{3}$ treated seed as compared to untreated control. Increase in shoot length was also comparable with captan treated seeds and it was significantly more than the untreated control. Vigour index was also maximum (11.06) in case of $\mathrm{NCuS}_{3}$ at $7 \mu \mathrm{g} /$ $\mathrm{ml}$ as compared to 10.53 obtained in captan treated seeds. At concentrations lower than $7 \mu \mathrm{g} / \mathrm{ml}$, the seed rot and seed blight increased with decreased in vigour index and other vital parameters. At concentration $\geq 8 \mu \mathrm{g} / \mathrm{ml}$ the phytotoxicity was observed with significant reduction in germination (Table 4).

The comparison of the results with $\mathrm{Cu}^{2+}$, copper $(\mathrm{Cu})$ nanoparticles and copper oxide $(\mathrm{CuO})$ nanoparticle reflects the edge of $\mathrm{NCuS}$ over other nano copper analogues. $\mathrm{Cu}^{2+}$ inflict high phytotoxic effects on seed application studies and toxicity was more than the chemically synthesized $\mathrm{CuO}$ nanoparticles (Saif et al. 2016). The results of germination enhancement were consistent with the increased germination on the application of $\mathrm{CuO}$ nanoparticles on Brassica napus (Atha et al. 2012) and Triticum aestivum (Farhat et al. 2015). The severe toxicity was further observed following severe reduction in seedling vigour, root length and shoot parameters by $\mathrm{CuO}$ and $\mathrm{Cu}$ nanoparticles. The increased germination in our results were at the concentrations as low as $7 \mu \mathrm{g} / \mathrm{ml}$ which were parallel with our previous in vitro results. Since sulfur and copper, both carry antifungal activities and their combination is much more effective than other nanoanalogues of copper. Side by side strong, thermally stable and non-hydrolysable linkage between $\mathrm{Cu}^{2+}$ and $\mathrm{S}^{2-}$ due to soft acidsoft base interaction makes release of $\mathrm{Cu}^{2+}$ ions (Wang et al. 2013) in aqueous media difficult, which is the main cause of lower toxicity copper toxicity in $\mathrm{NCuS}$.

\section{Conclusion}

Overall, NCuS have shown broad spectrum of activities against phytopathogenic fungi. The results of bioactivity were deca-fold better than the standard fungicide captan used. Copper sulfide is natural, non toxic and have been reported to get metabolised in human body to cure various ailments (Guo et al. 2013). Moreover copper and sulfur belongs to essential micro and macro nutrient for the living

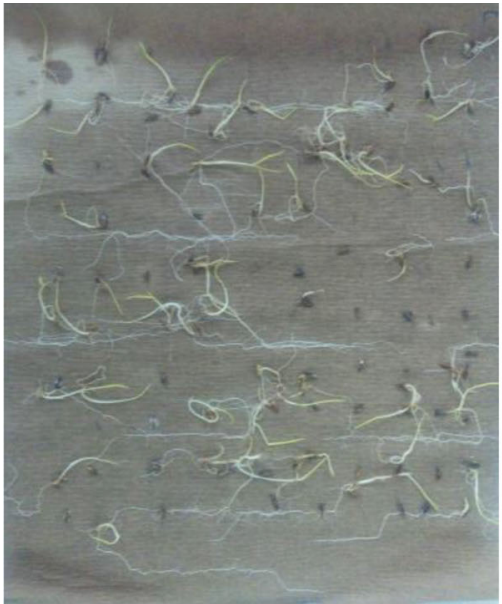

(a)

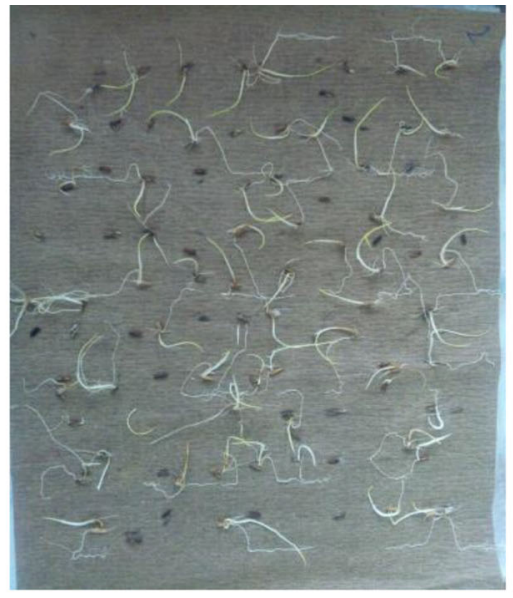

(b)

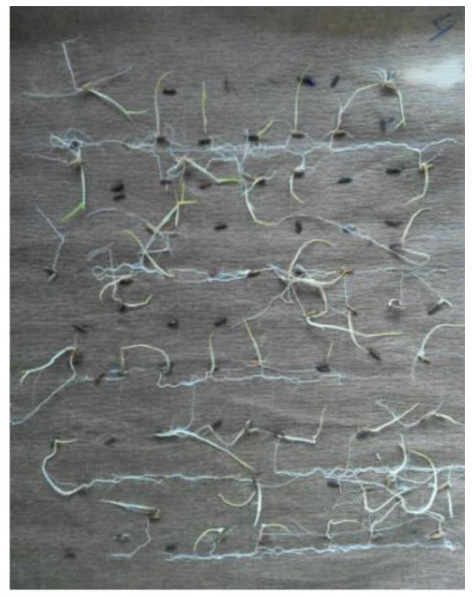

(c)

Fig. 9 The effect of $\mathrm{NCuS}_{3}$ on seed treatment of discoloured paddy seeds at $7 \mu \mathrm{g} / \mathrm{ml}$ a control, $\mathbf{b}$ captan, $\mathbf{c} \mathrm{NCuS}_{3}$ treatment 
Table 4 Effect of seed treatment with Captan and $\mathrm{NCuS}_{3}$ on seed rot, seedling blight and seed quality parameters of healthy and infected rice seeds

\begin{tabular}{|c|c|c|c|c|c|c|c|c|c|c|}
\hline \multirow[t]{2}{*}{ Treatment } & \multirow[t]{2}{*}{ Seed used } & \multicolumn{9}{|c|}{ Seed health and seed quality parameters } \\
\hline & & $\begin{array}{l}\text { Germination } \\
(\%)\end{array}$ & $\begin{array}{l}\text { Root } \\
\text { length } \\
(\mathrm{cm})\end{array}$ & $\begin{array}{l}\text { Shoot } \\
\text { length } \\
(\mathrm{cm})\end{array}$ & $\begin{array}{l}\text { Dry } \\
\text { weight } \\
(\mathrm{mg})\end{array}$ & $\begin{array}{l}\text { Vigour } \\
\text { index } \\
(\mathrm{VI})\end{array}$ & $\begin{array}{l}\text { Seed } \\
\text { rot } \\
(\%)\end{array}$ & $\begin{array}{l}\text { Reduction in } \\
\text { seed rot }(\%)\end{array}$ & $\begin{array}{l}\text { Seedling } \\
\text { blight }(\%)\end{array}$ & $\begin{array}{l}\text { Reduction in } \\
\text { seedling blight } \\
(\%)\end{array}$ \\
\hline \multirow[t]{4}{*}{$\mathrm{NCuS}_{3}$} & $\begin{array}{l}\text { Discoloured } \\
\text { @ } 5 \mu \mathrm{g} / \mathrm{ml}\end{array}$ & 77 & 7.98 & 2.20 & 0.12 & 9.24 & 19 & 52.5 & 7 & 76.6 \\
\hline & $\begin{array}{l}\text { Discoloured } \\
\quad @ 6 \mu \mathrm{g} / \mathrm{ml}\end{array}$ & 80 & 7.99 & 2.50 & 0.11 & 8.80 & 18 & 55 & 6 & 80 \\
\hline & $\begin{array}{l}\text { Discoloured } \\
\text { @ } 7 \mu \mathrm{g} / \mathrm{ml}\end{array}$ & 79 & 8.97 & 2.80 & 0.14 & 11.06 & 16 & 60 & 5 & 83.3 \\
\hline & $\begin{array}{l}\text { Discoloured } \\
\quad @ \geq 8 \mu \mathrm{g} / \\
\quad \mathrm{ml}\end{array}$ & $<50$ & \multicolumn{8}{|c|}{ Seedling mortality due to phyto-toxicity } \\
\hline $\begin{array}{l}\text { Captan } \\
\text { (standard } \\
\text { fungicide) }\end{array}$ & $\begin{array}{l}\text { Discoloured } \\
@ 0.25 \%\end{array}$ & 81 & 8.61 & 2.78 & 0.13 & 10.53 & 20 & 50 & 8 & 73.3 \\
\hline Water & Healthy & 82 & 10.55 & 3.36 & 0.17 & 13.94 & 3 & Nil & Nil & Nil \\
\hline $\begin{array}{l}\text { Untreated } \\
\text { (control) }\end{array}$ & Discoloured & 50 & 4.12 & 1.20 & 0.10 & 5.0 & 40 & Nil & 30 & Nil \\
\hline
\end{tabular}

${ }^{a}$ Standard dose for seed treatment

kingdom. Their multi times effectivity against the test fungi in comparison to the standards, along with non-poisonous effects, eco-friendly water based nature, low cost of production and easy synthesis demands their further exploitation in agricultural world. Their effect on seed quality further advocates their exploration and proper implementation as seed treatment agent which could significantly invigorate and accelerate seed germination and seedling growth.

Open Access This article is distributed under the terms of the Creative Commons Attribution 4.0 International License (http:// creativecommons.org/licenses/by/4.0/), which permits unrestricted use, distribution, and reproduction in any medium, provided you give appropriate credit to the original author(s) and the source, provide a link to the Creative Commons license, and indicate if changes were made.

\section{References}

Abdul-Baki AA, Anderson JD (1973) Vigour determination in soybean seed by multiple criteria. Crop Sci 13:630-633

Agnitotri S, Mukherji S, Mukherji S (2014) Size-controlled silver nanoparticles synthesized over the range 5-100 nm using the same protocol and their antibacterial efficacy. RSC Adv 4:3974-3983

Ajibade PA, Botha NL (2016) Synthesis and structural studies of copper sulfide nanocrystals. Results Phys 6:581-589

Atha DH, Wang HH, Petersen EJ, Cleveland D, Holbrook RD, Jaruga P, Dizdaroglu M, Xing BS, Nelson BC (2012) Copper oxide nanoparticle mediated DNA damage in terrestrial plant models. Environ Sci Technol 46:1819-1827
Ayodhya D, Venkatesham M, Kumari SA, Reddy GB, Ramakrishna D, Veerabhadram G (2016) Photocatalytic degradation of dye pollutants under solar, visible and UV lights using green synthesised CuS nanoparticles. J Exp Nanosci 11(6):418-432

Baek SW (2017) Artifical biomaterial comprising copper based compound. US Patent 2017/0035933A1

Baek SW, Kim MS (2017) Antibacterial filter comprising copperbased sulfur compound. US Patent 20160332104A1

Castillon-Barraza FF, Farias MH, Coronado-Lopez JH, EncinasRomero MA, Perez-Tello MP, Herrera-Urbina R, PosadaAmarillas A (2011) Synthesis and characterization of CuS NPs obtained by the polyol method. Adv Sci Lett 4:1-6

Chakraborty P, Adhikar J, Chatterjee S, Biswas B, Chattopadhyay T (2016) Facile synthesis of copper sulfide nanoparticles: antibacterial and antifungal activity study. Rasayan J Chem 9(1):77-83

Ding C, Wang Z, Zhong H, Zhang S (2010) Synthesis and biomedical application of copper sulfide nanoparticles: from sensors to theranostics. Biosens Bioelectron 25:1082-1089

Farhat Y, Abdul R, Iqbal MN, Hafiz MZ (2015) Effect of silver, copper and iron nanoparticles on wheat germination. Int $\mathrm{J}$ Biosci 6(4):112-117

Fu PP, Xia QS, Hwang HM, Ray PC, Yu HT (2014) Mechanisms of nanotoxicity: generation of reactive oxygen species. J Food Drug Anal 22:64-75

Gogos A, Knauer K, Bucheli TD (2012) Nanomaterials in plant protection and fertilization: current state, foreseen applications, and research priorities. J Agric Food Chem 60:9781-9792

Guanling S, Wenhua H, Yuan G, Yan W, Lin L, Zhiwei Z, Qiang N, Rulin M, Lati M, Haixia W (2016) Effects of CuO nanoparticles on Lemna minor. Bot Stud 57:3

Guo L, Panderi I, Yan DD, Szulak K, Li Y, Chen Y, Ma H, Niesen DB, Seeram N, Ahmed A, Yan B, Pantazatos D, Lu W (2013) A comparative study of hollow copper sulfide nanoparticles and hollow gold nanosphere on degradability and toxicity. ACA Nano 7(10):8780-8793

Han S, Liu W, Sun K (2016) Micro-scale self-assembly of long-range ordered CuS nanostructures. Microsc Microanal 22:1912-1913 
Hosseini MR, Schaffie M, Pazouki M, Darezereshki E, Ranjbar M (2012) Biologically synthesized copper sulfide nanoparticles: production and characterization. Mater Sci Semiconduc Process 15(2):222-225

http://www.azom.com/article.aspx?ArticleID=13694. Accessed 16 March 2017

Huang X, Hu N, Wang X, Zhang YS, Sun R (2017) Copper sulfide nanoparticles/cellulose composite paper: room temperature green fabrication for NIR laser-inducible ablation of pathogenic microorganisms. ACS Sustainable Chem Engg 5(3):2648-2655

ISTA (1999) International rules for seed testing. Seed Sci Technol $31: 1-152$

Juarez-Maldonado A, Ortega-Ortiz H, Perez-Labrada F, CadenasPliego G, Benavides-Mendoza A (2016) $\mathrm{Cu}$ nanoparticles absorbed on chitosan hydrogels positively alter morphological, production, and quality characteristics of tomato. J Appl Bot Food Qual 89:183-189

Kundu J, Pradhan D (2013) Influence of precursor concentration, surfactant and temperature on the hydrothermal synthesis of CuS: structural, thermal and optical properties. New J Chem 37:1470-1478

Liu RQ, Zhang HY, Lal R (2016) Effects of stabilized nanoparticles of copper, zinc, manganese, and iron oxides in low concentrations on lettuce (Lactuca sativa) seed germination: nanotoxicants or nanonutrients. Water Air Soil Pollut 227:1-14

Nafees M, Ikram M, Ali A (2015) Thermal behavior and decomposition of copper sulfide nanomaterial synthesized by aqueous sol method. Digest J Nanomater Biostruc 10:635-641

Nandipha LB (2015) Copper dithiocarbamate complexes and copper sulfide nanoparticles: synthesis, characterization and antifungal studies. Thesis, University of Fort Hare

Navarro E, Baun A, Behra R, Hartmann NB, Filser J, Miao AJ, Quigg A, Santchi PH, Sigg L (2008) Environmental behaviour and ecotoxicity of engineered nanoparticles to algae, plants and fungi. Ecotoxicology 17(5):372-386

Nene YL, Thapliyal PN (1993) Fungicides in Plant disease control, 3rd edn. Oxford and IBH Publishing Co Pvt Ltd, New Delhi, p 525

Prabhavathi SP, Ranjith Ranjam SR, Mauthamuthu Johnson T (2015) Microwave synthesis, characterization and biological activities of $\mathrm{CuS}$ and CdS nanoparticles. World J Pharma Res 4:710-720

Priyadharshini P, Rajagopal R (2015) Synthesis and characterization of metal doped nanocrystalline copper sulfide. Int J Recent Sci Res 6(4):3328-3331

Rani S (2016) Synthesis and antifungal evaluation of benzothiazol-2ylcarbamodithioates capped silver nanoparticles. Thesis, Punjab Agricultural University

Rao H, Sun W, Ye S, Yan W, Li Y, Peng H, Liu Z, Bian Z, Huang C (2016) Solution-processed $\mathrm{CuS} \mathrm{Nps}$ as an inorganic hole- selective contact material for inverted planar perovskite solar cells. ACS Appl Mater Interfaces 8:7800-7805

Richardson HW (1997) Handbook of copper compounds and applications. Marcel Dek-20 ker, Inc, New York, pp 93-122

Riyaz S, Parveen A, Azam A (2016) Microstructural and optical properties of $\mathrm{CuS}$ nanoparticles prepared by sol gel route. Dept Appl Phys 8:632-635

Ruttkay-Nedecky B, Krystofova O, Nejdl L, Adam V (2017) Nanoparticles based on essential metals and their phytotoxicity. J Nanobiotechnol 15:33. doi:10.1186/s12951-017-0268-3

Saif S, Tahir A, Asim T, Chen Y (2016) plant mediated green synthesis of $\mathrm{CuO}$ nanoparticles: comparison of toxicity of engineered and plant mediated $\mathrm{CuO}$ nanoparticles towards Daphnia magna. Nanomater 6(11):205. doi:10.3390/ nano6110205

Santra S (2014) Silica based antibacterial and antifungal nanoformulation. US Patent 8632811B1

Schneider KH, Karpov A, Voss H, Dunker S, Merk M, Kopf A, Kondo S (2011) Method for treating phytopathogenic microorganisms using surface-modified nanoparticulate copper salts. In patentscope, vol. WO/2011/067186

Shamsipur M, Pourmortazavi SM, Roushani M, Hajimirsadeghi SS (2013) Electrochemical preparation and thermal characterization of copper sulfide nanoparticles. Synth React Inorg Met Org Nano-Met Chem 44:951-958

Suja R, Geetha D, Ramesh P (2013) Preparation and characterization of $\mathrm{CuS}$ nanomaterials by solvothermal method. Int J Sci Eng Res 4(3): $1-3$

Torgeson DC (1967) Fungicides an advanced treatise, agricultural and industrial applications and environmental interaction, vol 1. Academic Press, New York, p 697

Wang Z, Bussche AVD, Kabadi PK, Kane AB, Hurt RH (2013) Biological and environmental transformation of copper-based nanomaterials. ACS Nano 7(10):8715-8727

Yang C, Lun M, Zou X, Xiang G, Chen W (2013) Surface plasmonenhanced $\mathrm{Ag} / \mathrm{CuS}$ nanocomposites for cancer treatment. Cancer Nano 4:81-89

You X, Geng X, Liu X, Yu Y, Jing Z (2017) A comparative study of the photocatalytic properties of $\mathrm{CuS}$ nanotubes and nanoparticles by hydrothermal method. Indian J Chem 56A:57-62

\section{Publisher's Note}

Springer Nature remains neutral with regard to jurisdictional claims in published maps and institutional affiliations. 